\title{
Distribution Characteristics of Nutrients in Wuleidao Bay and Jinghai Bay, Wendeng, China
}

\author{
Hongtao Li \\ Wendeng Marine Environmental Monitoring Station, Station Oceanic Administration \\ Wendeng, Weihai, China
}

Guoqing Yu

Wendeng Marine Environmental Monitoring Station, Station Oceanic Administration

Wendeng, Weihai, China

Xiaoyu Liu

Wendeng Marine Environmental Monitoring Station, Station Oceanic Administration

Wendeng, Weihai, China

Received: July 10, 2014 Accepted: August 7, 2014 Published: January 1, 2015

doi:10.5296/ast.v3i1.6089 URL: http://dx.doi.org/10.5296/ast.v3i1.6089

\begin{abstract}
To investigate the distribution characteristics of nutrients in Wuleidao Bay and Jinghai Bay, a survey for COD, nutrients, Chlorophyll $a(\mathrm{Chl} a)$, was conducted in May, August, October of 2013. The results showed that due to the seasonal discharge of sewage into the sea and phytoplankton cyclical life activities, both the salinity and nutrient concentrations within the two bays and at bay mouth were higher than those of further off the coast. From the estuaries seaward, the proportion of DIN in TN was raising, while TON in TN was reducing. $\mathrm{PO}_{4}^{-3}-\mathrm{P}$ was a limiting factor for phytoplankton growth, but had not yet become an absolute limiting factor. The monthly average of nitrogen, phosphorus molar ratio is in the following order, May>August $>$ October. The correlation between $\mathrm{Chl} a$ and $\mathrm{PO}_{4}{ }^{-3}-\mathrm{P}$ was higher than the correlation between Chl $a$ and DIN. DIN level could meet the second class standard of GB 8978-1996, while $\mathrm{PO}^{-3}$-P could meet fist class. Without considering COD, higher level of eutrophication was detected in August, while October was lower. When considering COD, August and October were both at a high level; however, both months did not reach the
\end{abstract}


eutrophication level.

Keywords: Wuleidao Bay, Jinghai Bay, Nutrient limiting factor, Nutrients distribution, Eutrophication 


\section{1) Macrothink}

\section{Introduction}

Wuleidao Bay and Jinghai Bay in Wendeng, China, are two adjacent open bays in the North Yellow Sea that separated by pier into the sea. Wuleidao Bay has Sow River and Chang Yang River estuary while Jinghai Bay contains Qinglong River estuary. The two Bays receive most of Wenden terrigenous sewage that is discharged into the sea. Thus the physical and chemical factors in this area are greatly impacted by the waters off the coast of the sea and the surrounding land-based sources of sewage into the sea.

With the growing population, booming economy, and the development and utilization of the hub in recent years, the environment of the two bays area and the adjacent water is seriously threatened. This paper summarize the sea water quality monitoring data of May, August, and October in 2013 to analyze and evaluate the distribution of nutrients and eutrophication level, in order to accurately understand the current status of the sea water environment, both for the protection of ecological environment in the Gulf and adjacent waters, and for providing the basis for sustainable use of resources.

\section{Materials and Methods}

\subsection{Study Area}

Within each of the two Bays and the bay mouths, one station was setup, namely stations A3, A1, A2, A6. One station (A4) was setup at the junction of the two Bays. Two additional stations (A5, A7) were setup in the outer sea area located adjacent to the two Bays. A total of seven stations were illustrated in Figure 1. Sample collections and measurement were conducted three times during May, August, October respectively.

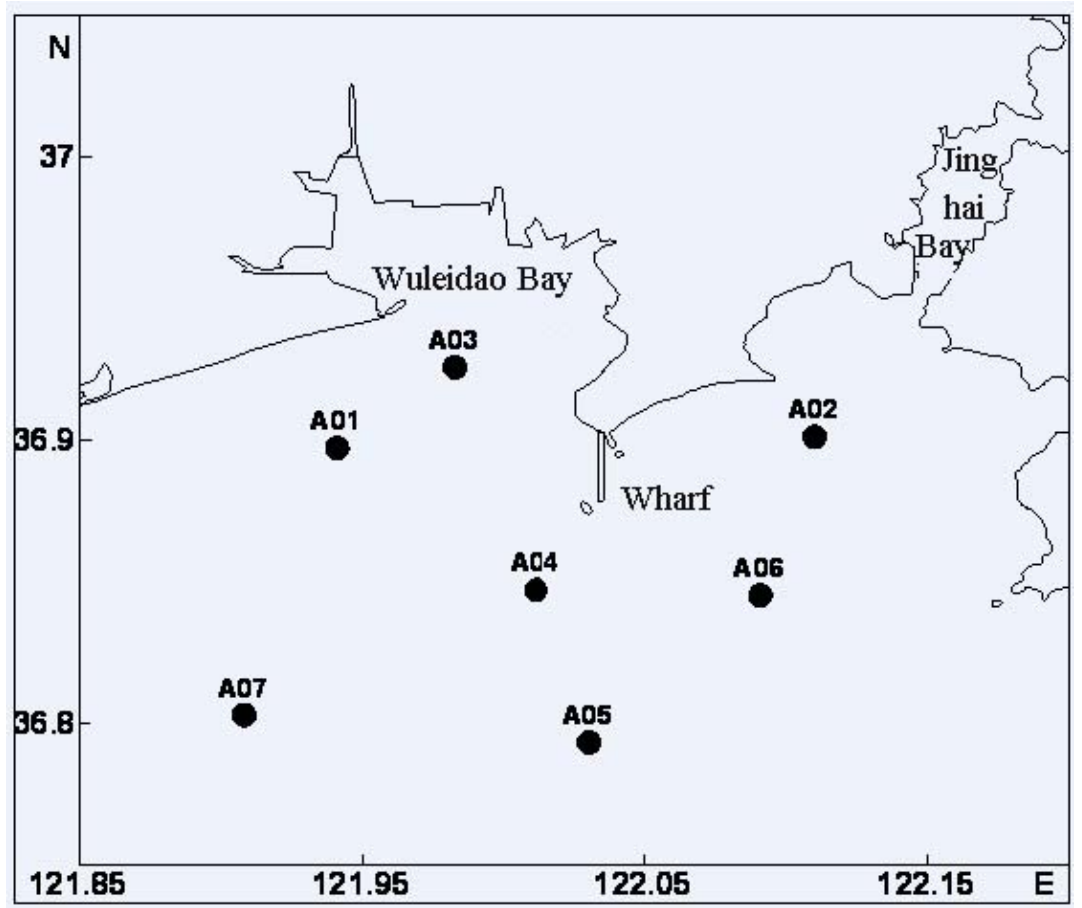

Figure 1. Sample stations in Wuliedao Bay and Jinghai Bay 


\subsection{Monitoring Indicators}

Due to the shallow depth of the two Bays, only the surface water was investigated. Surface water samples within $0.5 \mathrm{~m}$ deep were gathered at each survey station and the main measurements that were monitored include chemical oxygen demand (COD), ammonia $\left(\mathrm{NH}_{4}{ }^{+}-\mathrm{N}\right)$, nitrite salt nitrogen $\left(\mathrm{NO}_{2}^{-}-\mathrm{N}\right)$, nitrate nitrogen $\left(\mathrm{NO}_{3}^{-}-\mathrm{N}\right)$, total nitrogen $(\mathrm{TN})$, total organic nitrogen (TON), inorganic phosphate $\left(\mathrm{PO}_{4}^{-3}-\mathrm{P}\right)$, total phosphorus (TP) and chlorophyll a $(\mathrm{Chl} a)$.

\subsection{Analysis Methods}

The analysis methods were based on marine monitoring Part 4: Seawater Analysis (GB 17378.4-2007), marine survey - Part 4 of seawater chemical elements investigation (GBT 12763.4-2007), People's Republic of China water quality standards (GB3097-1997). The sum of Ammonia $\left(\mathrm{NH}_{4}{ }^{-} \mathrm{N}\right)$, nitrite $\left(\mathrm{NO}_{2}{ }^{-} \mathrm{N}\right)$, and nitrate nitrogen $\left(\mathrm{NO}_{3}{ }^{-} \mathrm{N}\right)$ is the dissolved inorganic nitrogen (DIN), the total organic nitrogen (TON) is calculated by subtracting DIN from TN.

\section{Results and Discussion}

\subsection{Nutrients Distribution Charateristics}

Distribution of nutrients of surface waters in October 2013 is show in Table 1 and Table 2.

Table 1. Sea water quality of Wuleidao Bay and Jinghai Bay in October 2013

\begin{tabular}{lllllllllll}
\hline \multirow{2}{*}{ Stations } & $\begin{array}{l}\mathrm{COD} \\
\mathrm{mg} / \mathrm{L}\end{array}$ & $\begin{array}{l}\mathrm{PO}_{4}^{-3}-\mathrm{P} \\
m g / L\end{array}$ & $\begin{array}{l}\mathrm{TP} \\
\mathrm{mg} / \mathrm{L}\end{array}$ & $\begin{array}{l}\mathrm{NO}_{2}{ }^{-}-\mathrm{N} \\
\mathrm{mg} / \mathrm{L}\end{array}$ & $\begin{array}{l}\mathrm{NO}_{3}{ }^{-}-\mathrm{N} \\
\mathrm{mg} / \mathrm{L}\end{array}$ & $\begin{array}{l}\mathrm{NH}_{4}{ }^{+}-\mathrm{N} \\
\mathrm{mg} / \mathrm{L}\end{array}$ & $\begin{array}{l}\mathrm{DIN} \\
\mathrm{mg} / \mathrm{L}\end{array}$ & $\begin{array}{l}\mathrm{TN} \\
\mathrm{mg} / \mathrm{L}\end{array}$ & $\begin{array}{l}\mathrm{TN}-\mathrm{DIN} \\
\mathrm{mg} / \mathrm{L}\end{array}$ & $\begin{array}{l}\text { Chl-a } \\
\mu g / L\end{array}$ \\
\hline $\mathrm{A} 01$ & 1.28 & 0.015 & 0.036 & 0.008 & 0.148 & 0.061 & 0.217 & 0.302 & 0.085 & 1.35 \\
$\mathrm{~A} 02$ & 1.30 & 0.014 & 0.023 & 0.005 & 0.141 & 0.057 & 0.201 & 0.254 & 0.053 & 1.23 \\
$\mathrm{~A} 03$ & 1.50 & 0.011 & 0.020 & 0.006 & 0.157 & 0.070 & 0.233 & 0.312 & 0.079 & 1.25 \\
$\mathrm{~A} 04$ & 1.12 & 0.012 & 0.022 & 0.006 & 0.141 & 0.048 & 0.195 & 0.246 & 0.051 & 1.24 \\
$\mathrm{~A} 05$ & 1.46 & 0.012 & 0.017 & 0.006 & 0.119 & 0.042 & 0.167 & 0.202 & 0.035 & 1.04 \\
$\mathrm{~A} 06$ & 1.58 & 0.011 & 0.024 & 0.007 & 0.139 & 0.055 & 0.203 & 0.238 & 0.035 & 1.04 \\
$\mathrm{~A} 07$ & 1.09 & 0.011 & 0.019 & 0.007 & 0.130 & 0.061 & 0.198 & 0.238 & 0.040 & 0.84 \\
Ave & 1.33 & 0.012 & 0.023 & 0.006 & 0.139 & 0.056 & 0.202 & 0.256 & 0.054 & 1.14 \\
\hline
\end{tabular}


Table 2. Proportion of nutrients in Wuleidao Bay and Jinghai Bay in October 2013

\begin{tabular}{|c|c|c|c|c|c|c|c|c|}
\hline Station & $\begin{array}{l}\mathrm{NO}_{2}^{-}-\mathrm{N} \\
/ \mathrm{DIN}\end{array}$ & $\begin{array}{l}\mathrm{NO}_{3}{ }^{-}-\mathrm{N} \\
/ \mathrm{DIN}\end{array}$ & $\begin{array}{l}\mathrm{NH}_{4}{ }^{-} \mathrm{N} \\
/ \mathrm{DIN}\end{array}$ & $\begin{array}{l}\mathrm{NH}_{4}{ }^{+}-\mathrm{N} \\
/ \mathrm{NO}_{3}{ }^{-}-\mathrm{N}\end{array}$ & DIN & $\mathrm{DIN} / \mathrm{TN}$ & $\begin{array}{l}\mathrm{DIN} \\
/ \mathrm{PO}_{4}^{-3}-\mathrm{P}\end{array}$ & $\begin{array}{l}\left(\mathrm{TP}-\mathrm{PO}_{4}^{-3}-\mathrm{P}\right) \\
/ \mathrm{TP}\end{array}$ \\
\hline A01 & 0.037 & 0.682 & 0.281 & 0.412 & 0.217 & 0.719 & 32.0 & 0.583 \\
\hline A02 & 0.025 & 0.695 & 0.281 & 0.404 & 0.203 & 0.799 & 32.1 & 0.391 \\
\hline A03 & 0.026 & 0.674 & 0.3 & 0.445 & 0.233 & 0.747 & 46.9 & 0.450 \\
\hline A04 & 0.031 & 0.723 & 0.246 & 0.34 & 0.195 & 0.793 & 36.0 & 0.455 \\
\hline A05 & 0.036 & 0.713 & 0.251 & 0.352 & 0.167 & 0.827 & 30.8 & 0.294 \\
\hline A06 & 0.035 & 0.692 & 0.274 & 0.396 & 0.201 & 0.845 & 40.5 & 0.542 \\
\hline A07 & 0.035 & 0.657 & 0.308 & 0.469 & 0.198 & 0.832 & 39.9 & 0.421 \\
\hline Ave. & 0.032 & 0.690 & 0.279 & 0.404 & 0.202 & 0.789 & 36.4 & 0.466 \\
\hline
\end{tabular}

\subsubsection{Nutrient Nitrogen}

Nitrate $\left(\mathrm{NO}_{3}{ }^{-} \mathrm{N}\right)$ concentrations were in the range of $0.119-0.157 \mathrm{mg} / \mathrm{L}$, with an average of $0.139 \mathrm{mg} / \mathrm{L}$. The highest concentration was found in Wuleidao Bay (station A03, 0.157mg / L) and the mouth of the bay (station A01 , $0.148 \mathrm{mg} / \mathrm{L}$ ), followed by the Jinghai Bay (stand A02, $0.141 \mathrm{mg} / \mathrm{L}$ ) and the junction of two Bay (station A04, $0.141 \mathrm{mg} / \mathrm{L}$ ), the concentrations were lower for other stations, namely, Jinghai Bay Port (A06, $0.139 \mathrm{mg} / \mathrm{L}$ ), adjacent to the outer waters (station A07, $0.130 \mathrm{mg} / \mathrm{L}$, stand A05, $0.119 \mathrm{mg} / \mathrm{L}$ ), as shown in Figure 2. Figure 2 indicates that concentration within the two bays was significantly higher than the open sea, from the bay within the Gulf have a stripe of high concentration extend to the water outside. The reason is that the two Bays receive a large number of land-based sources of sewage into the sea. In addition, the discharge of sow River and Changyang rivers into the sea is greater than Qinglong River, resulting in the concentrations of Wuleidao Bay and Bay Port higher than Jinghai Bay. The two Bays merge at the southernmost part of the pier, where the effects that wharf embankment hinder currents disappeared. The concentration was getting lower seaward because of the dilution of the seawater and the lowest concentration was found at A05 station.

Ammonia $\left(\mathrm{NH}_{4}{ }^{+}-\mathrm{N}\right)$ concentrations varied from $0.042-0.070 \mathrm{mg} / \mathrm{L}$. The average concentration was $0.056 \mathrm{mg} / \mathrm{L}$. A high concentration appeared in Wuleidao Bay, Bay estuary and outside area, followed by the concentration of inside Jinghai Bay, outside Jinghai Bay. The concentration was low at the junction of two Bay and decreased seaward (Figure 3). Figures 3 shows, within each of the two bays, two high concentrations stripe of waters extend seaward with a low concentration band in between. The distributions of ammonia and nitrate nitrogen concentrations are similar, however, ammonia concentration gradient is smaller and high concentration stripe of water of Wuleidao Bay extends to the adjacent outer waters. Change from an oxidative environment to and reductive environment indicates the elevation of nutrient level of the water body (Stumm et al., 1996). Quriós (2003) further proposed that the increase of reduced state of nitrogen, $\mathrm{NH}_{4}{ }^{+}-\mathrm{N}$, and the decrease of the oxidized state of nitrogen, $\mathrm{NO}_{3}{ }^{-} \mathrm{N}$ directly reflects this shift, nutrient levels in water bodies will increase as $\mathrm{NH}_{4}{ }^{+}-\mathrm{N} / \mathrm{NO}_{3}{ }^{-}-\mathrm{N}$ increases. Table 2 shows that within the seven stations, this ratio is lowest at 


\section{Macrothink}

A04, A05, the two stations off the coast, the ratio at station A07 and Wuleidao Bay is the highest and Jinghai Bay has a medium ratio, which indicate that the lowest level of nutrition waters is off the coast, while the station A07 and the Wuleidao Bay have the highest level of nutrition (A07 is in oyster farming areas, which may be related to the culture environment and need for further research). One reason is that nutrient-rich phytoplankton blooms nearby river estuary. Phytoplankton first consumes ammonia (Bricelj \& Lonsdale, 1997; Feng et al., 1999), resulting in the gradual digestion of ammonia near the mouth of the river. Thus the ammonia cannot continue to spread into the sea. Another reason is the abundant biomass at the bay area, which can decompose dead organisms and produce $\mathrm{NH}_{4}{ }^{+}-\mathrm{N}$.

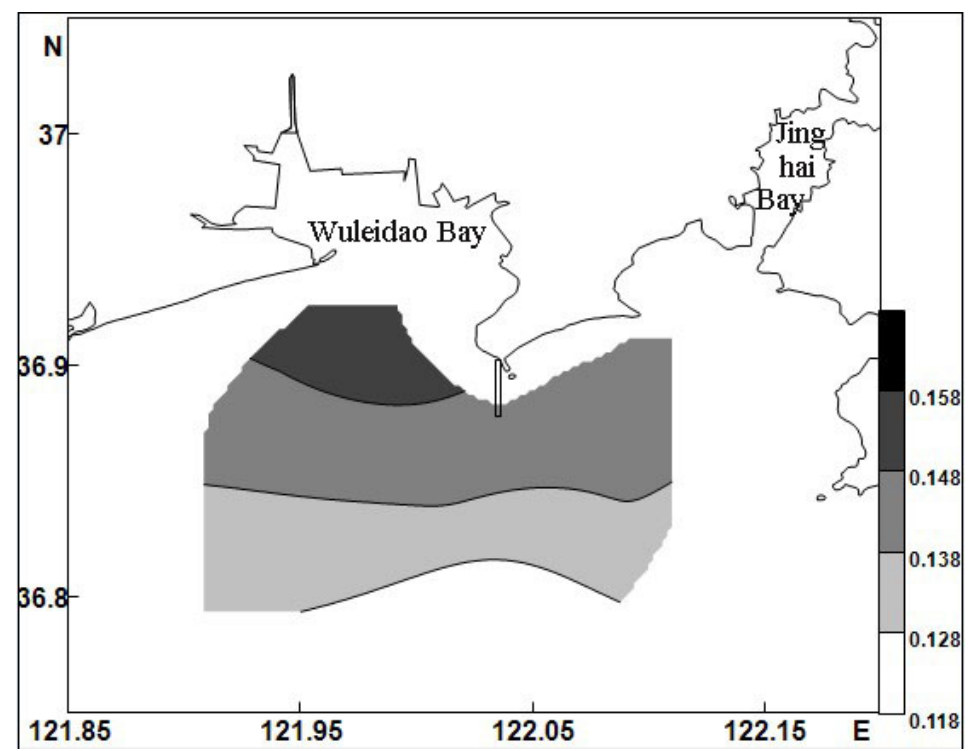

Figure 2. $\mathrm{NO}_{3}{ }^{-}-\mathrm{N}$ concentration profiles in Wuleidao Bay, and Jinghai Bay in October 2013

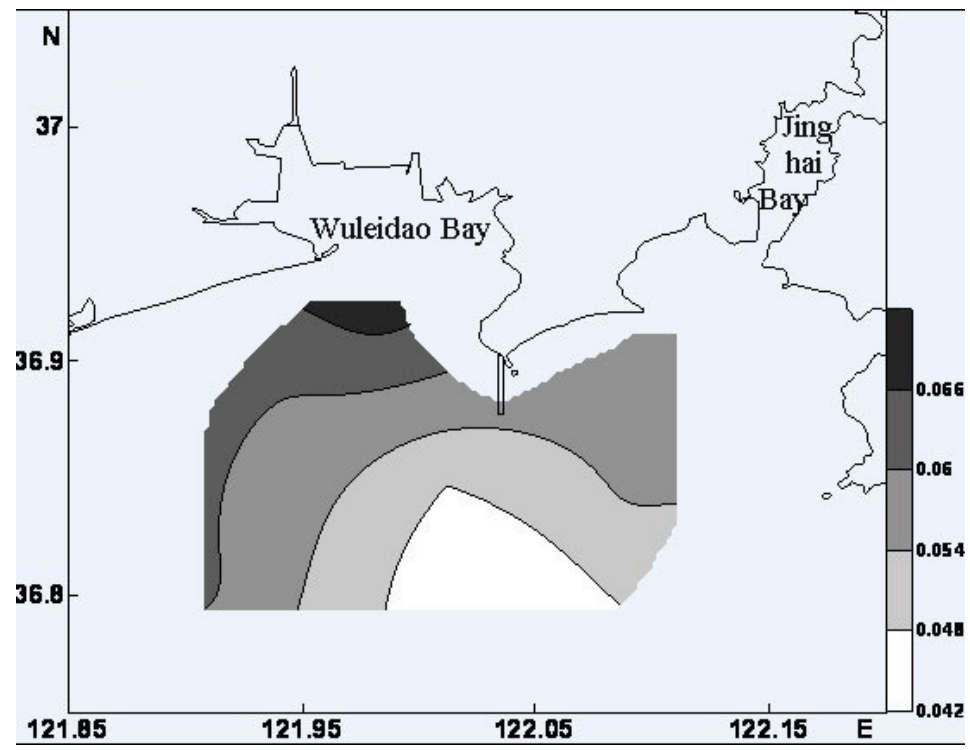

Figure 3. $\mathrm{NH}_{4}{ }^{+}-\mathrm{N}$ concentration profiles in Wuleidao Bay and Jinghai Bay in October 2013 


\section{$\triangle 1$ Macrothink}

Nitrite $\left(\mathrm{NO}_{2}^{-}-\mathrm{N}\right)$ ranged of $0.005-0.008 \mathrm{mg} / \mathrm{L}$, the highest concentration was still at the Wuleidao Bay (A01, $0.008 \mathrm{mg} / \mathrm{L}$ ), the concentration distribution was smooth and no significant changes was observed, as shown in Figure 4.

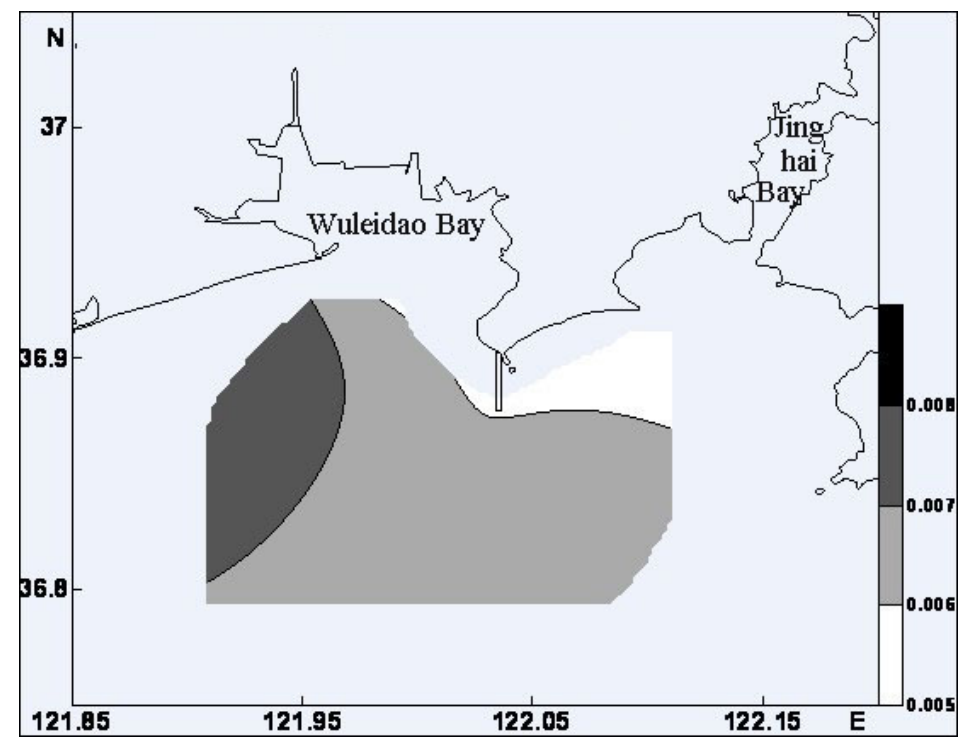

Figure 4. $\mathrm{NO}_{2}^{-}-\mathrm{N}$ concentration profiles in Wuleidao Bay in October 2013

The range of the dissolved inorganic nitrogen (DIN) concentration was $0.167-0.233 \mathrm{mg} / \mathrm{L}$ and the average concentration was $0.202 \mathrm{mg} / \mathrm{L}$. The highest concentration was detected in the Wuleidao Bay and the mouth of the bay, followed by the Jinghai Bay and the mouth of the bay, the low concentration area appeared at the junction of the two Bays, as shown in Figure 5. Figure 5 also showed that the concentration was higher at the Wuleidao Bay than Jinghai Bay. Within each of the two bays, a high concentration stripe of water extends seaward. The concentration was reducing seaward from the junction of the two Bays. The distribution of DIN concentration was similar to that of nitrate nitrogen, ammonia. Table 2 showed that the main ingredients of DIN was nitrate nitrogen, which accounts for $69.0 \%$ of DIN on average, followed by ammonia (27.9\%), and nitrite nitrogen accounts for only $3.2 \%$. The variation of the proportion of these three ingredients at different stations was small. The facts that nitrate nitrogen dominant in DIN suggested that the sea water was in an oxidative environment, which was beneficial for the self-purification of water bodies. Two off coast station A04 and A05 had the highest proportion of nitrate nitrogen and the lowest proportion of ammonia, indicated that the off coast waters have a better oxidative environment and higher water self-purification capacity. The four stations that meet the second class standard were distributed within the two Bays, Bay estuary and outside of the bay, the three stations which meeted the first class standard were located in the junction of two Bays and off the coast. 


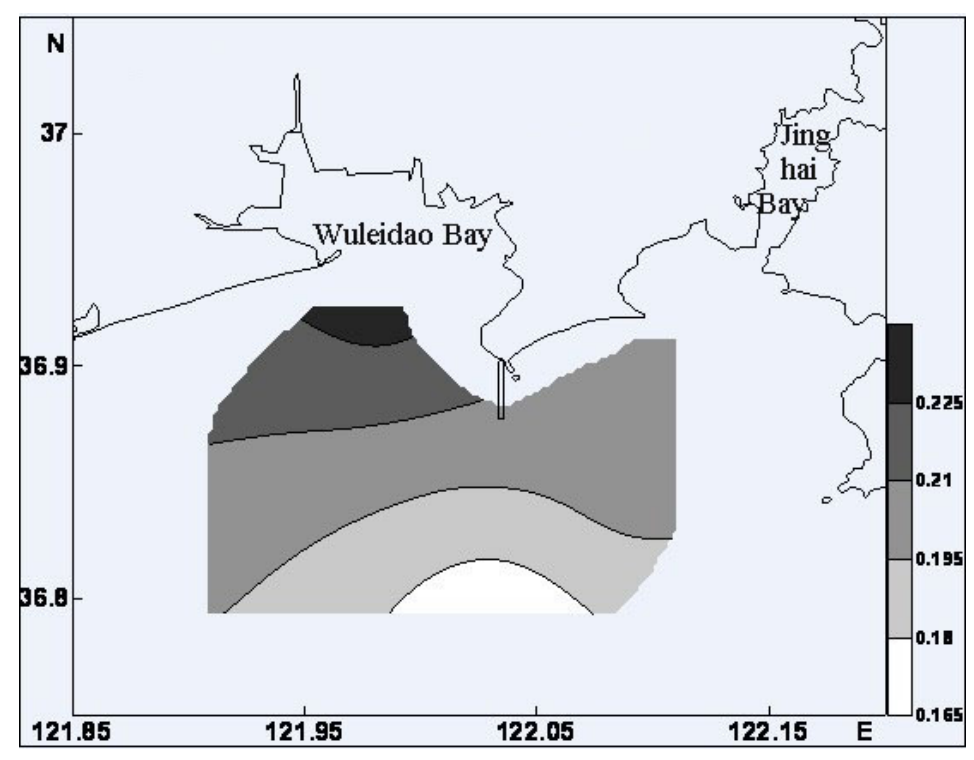

Figure 5. DIN concentration profile in Wuleidao Bay and Jinghai Bay in October 2013

Total nitrogen (TN) concentration varies in the range of $0.202-0.312 \mathrm{mg} / \mathrm{L}$ and the average concentration was $0.256 \mathrm{mg} / \mathrm{L}$. The highest concentration was in the Wuleidao Bay and the mouth of the bay, followed by the Jinghai Bay. Low concentrations were at the junction of the two Bays and off coast regions, as shown in Figure 6. Figure 6 demenstrated that TN concentration was higher in Wuleidao Bay than in Jinghai Bay. Within each of the two bays, a high concentration stripe of water extended seaward. The concentration was lowest at the junction of the two Bays and off coast regions. The distribution of the TN concentration was similar to that of DIN, nitrate nitrogen, ammonia. Table 2 showed that the DIN proportion of the TN ranges from $71.9 \%$ to $84.5 \%$, with an average of $78.9 \%$. The lowest proportion of DIN was at Wuleidao Bay mouth and within the bay, followed by the junction of two Bays and the Jinghai Bay. The highest proportion sites were the offshore sites suggested that the DIN proportion was increasing from the estuary seaward. Because of that TN includes two kinds of components, namely, DIN and TON (including dissolved and particulate organic nitrogen), it can be deducted that the proportion of TON in TN is decreasing from the estuary seaward. This is due to the higher nutrient concentrations in the inner bay area resulted from phytoplankton blooms. Because of the photosynthesis of phytoplankton and aquatic plants, DIN was assimilated into organic protein and other forms of organic nitrogen (Odun, 1981). In addition, organic nitrogen including urea etc. that entering the Gulf was directly absorbed and fixed by the phytoplankton in the bay and the bay mouth. Thus, TON proportion in TN was higher within the Bay and at Bay Estuary than that of the open sea. Since TON was the energy storage form of the nitrogen elements, TON proportion in TN increases as the overall level of productivity of the water increases (Wetzel, 2001). High TON proportion within the Bay and at the mouth of the bay also suggests the nutrient levels are higher at the inner bay and Bay Estuary than that of the open sea. 


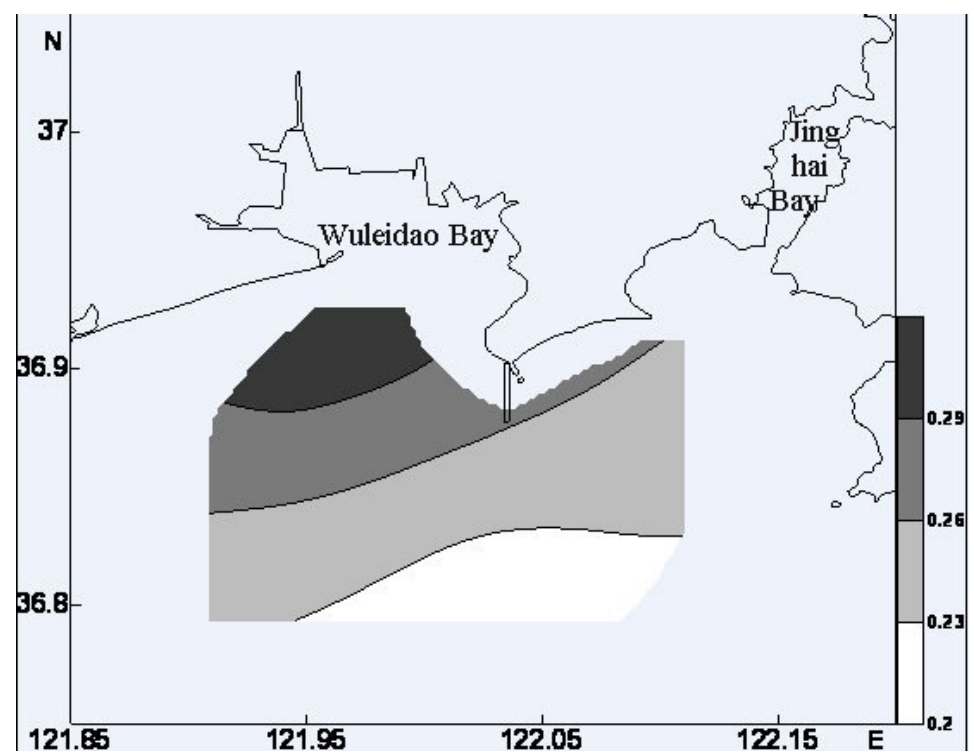

Figure 6. TN concentration profile in Wuleidao Bay and Jinghai Bay in October 2013

\subsubsection{Phosphorus Nutrient}

Inorganic phosphate $\left(\mathrm{PO}_{4}{ }^{-3}-\mathrm{P}\right)$ concentrations varied from $0.011-0.015 \mathrm{mg} / \mathrm{L}$ and the average concentration was $0.012 \mathrm{mg} / \mathrm{L}$. Changes in the concentration at each site was minimal and the trend of the change was not obvious. The sea water quality at all sites were compliance meeting the first class standard; however, the concentrations were close to the upper limit of first class standard.

Under normal circumstances, the molar ratio of seawater phytoplankton absorption of nitrogen and phosphorus is $16: 1$, which is the constant absorption ratio known as the Redfield coefficient. Nitrogen, phosphorus molar concentration ratio deviate either high or low from this coefficient can lead to a bottleneck in the growth of phytoplankton by the relatively low concentration element. This element which limit the growth of phytoplankton is a nutrient limiting factors (Brzezinski, 1985; Duvravko, 1995); If $\mathrm{N} / \mathrm{P}>22$, then the limiting element is phosphorus, If the $\mathrm{N} / \mathrm{P}<10$, the nitrogen is limiting element (Dortch \& Whitledge, 1992; Duvravko, 1995). According to the absolute limit rules JUSTIC et al. proposed, nutrient absorption kinetics studies indicate that phytoplankton growth requires the DIN and inorganic phosphorus threshold concentrations were $0.014 \mathrm{mg} / \mathrm{L}$, and $0.003 \mathrm{mg} / \mathrm{L}$ respectively (Justic et al., 1995; Zhang et al., 1997; Yang et al., 2001); Table 2 shows that nitrogen, phosphorus ratios at the seven stations are in the range of 30.8:1 - 46.9:1 with an average of 36.4:1, which are all greater than 22:1. Since nitrogen and phosphorus concentration ratios exceed the threshold, phosphorus is the limiting factor, but not an absolute limiting factor in this area.

Total phosphorus (TP) concentrations vary from $0.017-0.036 \mathrm{mg} / \mathrm{L}$ with an average of 0.023 $\mathrm{mg} / \mathrm{L}$. The high concentration point is in Wuleidao Bay mouth, followed by Jinghai Bay, and off coast regions have relatively low concentrations, as shown in Figure 7 (2013.10 total phosphorus). Permissive concentrations of total phosphorus are generally considered as under 


\section{Macrothink}

$0.030 \mathrm{mg} / \mathrm{L}$ in seawater (Entsch et al., 1983). Only A01 station with a concentration of 0.036 $\mathrm{mg} / \mathrm{L}$ exceeds the allowable amount, indicating that only Wuleidao Bay mouth TP value is high. Other waters' TP are within the normal range. The sum of the dissolved organic phosphorus (DOP) and particulate phosphorus (TPP) can be calculated by subtracting the $\mathrm{PO}_{4}{ }^{-3}-\mathrm{P}$ concentration from TP concentration and the results show that the sums of the two concentrations were between $0.005-0.021 \mathrm{mg} / \mathrm{L}$ with an average of $0.011 \mathrm{mg} / \mathrm{L}$, as shown in Table 2. The concentration of the two Bay mouths and the inner bays concentrations are higher than that of the open sea. The proportion of TP also showed the similar trend, which is higher at two Bay mouths, the inner bay, and lower off the coast. Such distribution is because, 1) The major source of marine phosphorus is from river inputs (Froelich, 1982) and the estuary of the river contains large amount of suspended material, which made it easy for $\mathrm{PO}_{4}{ }^{-3}-\mathrm{P}$ to be adsorbed on these suspended particles and become TPP. Away from the estuary, the high salinity makes it easy for $\mathrm{PO}_{4}^{-3}-\mathrm{P}$ to isolate from TPP; 2) The DOP is the product of phytoplankton secretion and zooplankton excretion. Thus its distribution is mainly affected by biological activities (Pomeroy \& Simith, 1965; George \& Willianms, 1985). Similar to that of the organic nitrogen, the phytoplankton, proliferated in the Gulf and nearby the estuary, fixes $\mathrm{PO}_{4}^{-3}-\mathrm{P}$ to organic phosphorus and particulate phosphorus. Such organic phosphorus and particulate phosphorus then stranded in the bay mouth under the effect of the tides.

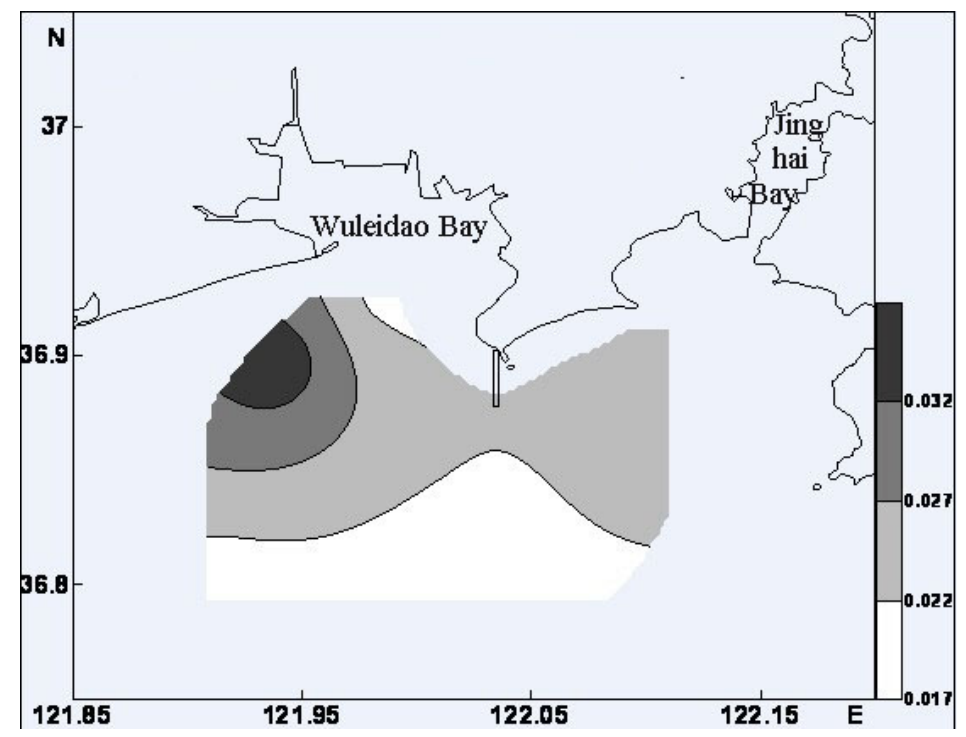

Figure 7. TP concentration profile in Wuleidao Bay and Jinghai Bay in October 2013

\subsubsection{Chlorophyll $a$}

Chl $a$ concentration rangeed from 0.84 to $1.35 \mu \mathrm{g} / \mathrm{L}$ with an average concentration of 1.14 $\mu \mathrm{g} / \mathrm{L}$. Wuleidao Bay mouth had the highest concentration, followed by Jinghai Bay, off the coast had the lowest concentration. Its distribution was similar to that of other nutrients especially TP (Figure 8). Since Chl $a$ is produced by photosynthesis of phytoplankton, the 
concentration of Chl $a$ is positively correlated with the phytoplankton concentration, which indicate that the amount of phytoplankton is higher at the two Bay mouth and inner bay area. The results of correlation analysis between $\mathrm{Chl} a$ and nitrogen, phosphorus concentration were shown in Table 3.

Table 3. Correlation of Chl $a$ and concentration of $\mathrm{N}, \mathrm{P}$

\begin{tabular}{lllllll}
\hline & $\mathrm{PO}_{4}{ }^{-3}-\mathrm{P}$ & $\mathrm{TP}$ & $\mathrm{TP}-\mathrm{PO}_{4}^{-3}-\mathrm{P}$ & $\mathrm{DIN}$ & $\mathrm{TN}$ & TN-DIN \\
\hline $\mathrm{r}$ & 0.6507 & 0.6117 & 0.5390 & 0.4853 & 0.6719 & 0.7838 \\
$\mathrm{n}$ & 7 & 7 & 7 & 7 & 7 & 7 \\
\hline
\end{tabular}

Chl $a$ was positively correlated with both nitrogen and phosphorus concentrations, which indicated that nutrient-rich waters corresponds to high $\mathrm{Chl} a$ concentration and abundant phytoplankton. The correlation between $\mathrm{Chl} a$ and $\mathrm{PO}_{4}{ }^{-3}-\mathrm{P}$ is higher than the correlation between Chl $a$ and DIN suggests planktonic biomass and $\mathrm{PO}_{4}{ }^{-3}-\mathrm{P}$ concentration have more closely relationship, which confirms the limiting factor in this area is $\mathrm{PO}_{4}{ }^{-3}-\mathrm{P}$ instead of DIN. The positive correlation with (TN-DIN), (TP-PO $\left.{ }_{4}^{-3}-\mathrm{P}\right)$ of demonstrate that the large population of phytoplankton in two Bay mouth and inner bay area fixed a large amount of nitrogen, phosphorus, which confirms the concentrations of nitrogen and phosphorus in organic and particulate form is higher at that the two Bay mouth and inner bay region.

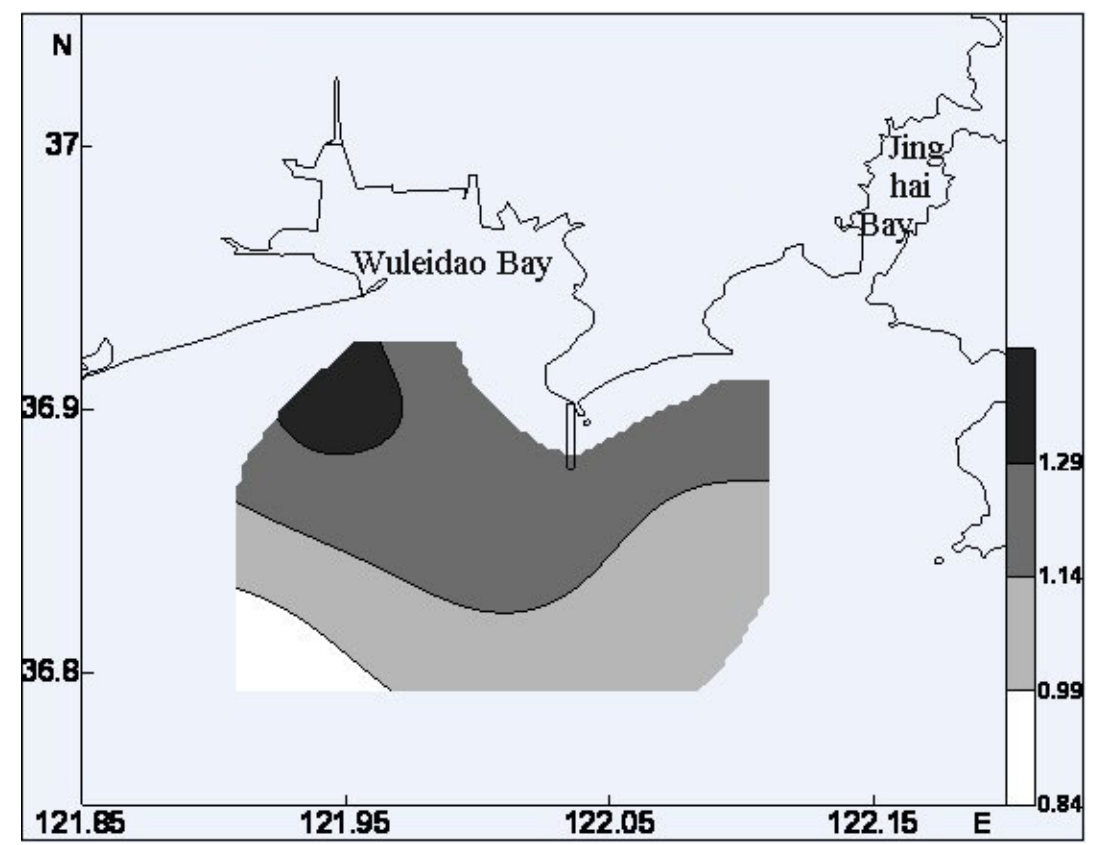

Figure 8. Chl-a concentration profile in Wuleidao Bay and Jinghai Bay in October 2013 


\subsection{Characteristics of Seasonal Distribution}

Study of seasonal distribution of nutrients in the surface water according to three research voyage conducted in March, May, and October, 2013, as shown in Table 4, Table 5 and Table 6.

Table 4. Nutrient concentrations in Wuleidao Bay and Jinghai Bay in May, August, October, 2013

\begin{tabular}{|c|c|c|c|c|c|c|c|c|c|c|}
\hline \multirow[t]{2}{*}{ Month } & & COD & $\mathrm{NO}_{2}-\mathrm{N}$ & $\mathrm{NO}_{3}{ }^{-}-\mathrm{N}$ & $\mathrm{NH}_{4}^{+}-\mathrm{N}$ & & & $\mathrm{PO}_{4}^{-3}-\mathrm{P}$ & & \\
\hline & & $\mathrm{mg} / \mathrm{L}$ & $m g / L$ & $m g / L$ & $m g / L$ & $m g / L$ & $m g / L$ & $m g / L$ & $m g / L$ & $\mu g / L$ \\
\hline \multirow{2}{*}{ May } & range & $0.80-1.33$ & $0.006-0.008$ & $0.105-0.152$ & $0.044-0.075$ & $0.156-0.233$ & $0.190-0.327$ & $0.006-0.014$ & $0.018-0.032$ & $0.95-2.14$ \\
\hline & Ave. & 0.94 & 0.007 & 0.134 & 0.063 & 0.203 & 0.25 & 0.009 & 0.026 & 1.47 \\
\hline \multirow{2}{*}{ Aug. } & range & $0.96-1.57$ & $0.006-0.008$ & $0.111-0.164$ & $0.051-0.082$ & $0.169-0.252$ & $0.206-0.325$ & $0.010-0.015$ & $0.016-0.039$ & $0.50-1.74$ \\
\hline & Ave. & 1.18 & 0.007 & 0.141 & 0.069 & 0.216 & 0.265 & 0.012 & 0.028 & 1.2 \\
\hline \multirow{2}{*}{ Oct. } & range & $1.09-1.58$ & $0.005-0.008$ & $0.119-0.157$ & $0.042-0.070$ & $0.167-0.233$ & $0.202-0.312$ & $0.011-0.015$ & $0.017-0.036$ & $0.84-1.35$ \\
\hline & Ave. & 1.33 & 0.006 & 0.139 & 0.056 & 0.202 & 0.256 & 0.012 & 0.023 & 1.14 \\
\hline \multirow{2}{*}{ Yearly } & range & $0.80-1.58$ & $0.005-0.008$ & $0.105-0.164$ & $0.042-0.082$ & $0.156-0.252$ & $0.190-0.327$ & $0.006-0.015$ & $0.016-0.039$ & $0.50-2.14$ \\
\hline & Ave. & 1.15 & 0.007 & 0.138 & 0.063 & 0.207 & 0.257 & 0.011 & 0.026 & 1.27 \\
\hline
\end{tabular}

Table 5. Proportion of each nutrient in Wuleidao Bay and Jinghai Bay in May, August, October, 2013

\begin{tabular}{|c|c|c|c|c|c|c|c|}
\hline $\begin{array}{l}\text { Mont } \\
\mathrm{h}\end{array}$ & $\begin{array}{l}\mathrm{NO}_{2}{ }^{-}-\mathrm{N} / \mathrm{DI} \\
\mathrm{N}\end{array}$ & $\begin{array}{l}\mathrm{NO}_{3}{ }^{-}-\mathrm{N} / \mathrm{DI} \\
\mathrm{N}\end{array}$ & $\begin{array}{l}\mathrm{NH}_{4}{ }^{+}-\mathrm{N} / \mathrm{DI} \\
\mathrm{N}\end{array}$ & $\begin{array}{l}\mathrm{NH}_{4}{ }^{+}-\mathrm{N} / \\
\mathrm{NO}_{3}^{-}-\mathrm{N}\end{array}$ & $\mathrm{DIN} / \mathrm{TN}$ & $\begin{array}{l}\mathrm{DIN} / \mathrm{PO}_{4}^{-{ }^{-3}} \\
\mathrm{P}\end{array}$ & EI \\
\hline May & 0.034 & 0.660 & 0.309 & 0.470 & 0.812 & 48.5 & 0.40 \\
\hline Aug. & 0.032 & 0.653 & 0.318 & 0.489 & 0.815 & 40.4 & 0.67 \\
\hline Oct. & 0.030 & 0.688 & 0.279 & 0.403 & 0.789 & 36.4 & 0.74 \\
\hline
\end{tabular}

Table 6. N, P molar ratio in Wuleidao Bay and Jinghai Bay

\begin{tabular}{lllll}
\hline Station & May & Aug. & Oct. & Ave. \\
\hline A01 & 82.3 & 37.5 & 32.0 & 42.8 \\
A02 & 46.1 & 31.4 & 32.1 & 35.4 \\
A03 & 39.7 & 46.5 & 46.9 & 44.2 \\
A04 & 31.6 & 42.5 & 36.0 & 36.3 \\
A05 & 57.6 & 34.0 & 30.8 & 37.6 \\
A06 & 75.7 & 47.6 & 40.5 & 50.9 \\
A07 & 44.1 & 48.1 & 39.9 & 43.9 \\
Ave. & 48.5 & 40.4 & 36.4 & 41.2 \\
\hline
\end{tabular}




\section{MInstitute ${ }^{\text {Mink }}$}

Table 4 shows that within the three months, August has the highest concentration of different forms of nitrogen nutrients and TP than that of May and October. $\mathrm{PO}_{4}{ }^{-3}-\mathrm{P}$ concentrations are high and close in August and October. May has the lowest concentration of $\mathrm{PO}_{4}{ }^{-3}-\mathrm{P}$. The reason is the heavy rain in August, which results in the two bays receiving large amount of sewage from the Sow River and ChangYang River. This leads to an increased concentration for each of nutrients. The highest concentration of Chl $a$ appears in May $(1.47 \mu \mathrm{g} / \mathrm{L})$. Concentrations in August and October are similar, which is consistent with the fact that phytoplankton blooms during May and make this period of time red tide prone. Annual average data show that only DIN meets the second class standard while all other indicators are in line with a class I sea water quality standard. Overall, seawater quality is clean.

Table 5 shows that during these three months, $\mathrm{NO}_{3}{ }^{-} \mathrm{-N}$ consists the largest portion of the DIN $(65.3 \%-68.8 \%)$, followed by $\mathrm{NH}_{4}{ }^{+}-\mathrm{N}(27.9 \%-31.8 \%)$, and the $\mathrm{NO}_{2}{ }^{-}-\mathrm{N}$ consist the smallest portion $(3.0 \%-3.4 \%)$. The change in the proportion is minimal in these months. $\mathrm{NH}_{4}{ }^{+}-\mathrm{N} / \mathrm{NO}_{3}{ }^{-}-\mathrm{N}$ derived from the Quriós' method (2003) is at the highest value in August and at lowest in October, which indicates that the sea water nutrient levels is the highest in August and lowest in October. The ratio DIN/TN is close in May and August, while the lowest is in October. It is probably because of the reduced rainfall, which resulted in the reduction of terrestrial input of nutrients. However, photosynthesis of phytoplankton continues to consume DIN and convert DIN to organic nitrogen. In addition, during October, the low water temperature slows the conversion of organic nitrogen into DIN by the decomposition biological remains. Thus, the proportion of DIN in TN becomes small. However, because of the sustained oxidative decomposition of the biological remains during winter and the intensive convection of the sea water, nutrients are released (Zhang, 2004). During this period of time, photosynthesis phytoplankton is weakened and the DIN consumption is reduced. These effects plus the continued accumulation of terrestrial DIN facilitate the DIN concentration slowly return to a high level. The Eutrophication index $\mathrm{EI}=(\mathrm{COD} \times \mathrm{DIN} \times$ $\mathrm{DIP}) \times 106 / 4500$, units are $\mathrm{mg} / \mathrm{L}, \mathrm{EI} \geq 1$ as eutrophication and the higher the $\mathrm{EI}$ the greater the degree of eutrophication (Sun et al., 2006; Li et al., 2007; He et al., 2008). This method adopted COD as a parameter. Table 5 shows that the index reaches its lowest (0.40) in May, 0.67 in August and its highest (0.76) in October. This result indicates that eutrophication level of August and October is higher than that of May; however, both of the months did not reach the level of eutrophication. The conclusion regarding October is in contrary with the result from Quriós' method. The reason is the introduction of COD in the EI index. October has the highest level of COD, which lead to an increased EI index during October. When COD is not considered, the level of eutrophication is high in August and low in October. Both August and October are at a high level, but did not reach the level of eutrophication, if the COD is taken into account.

In Table 6, by calculating the average nitrogen and phosphorus molar ratio in different month we found that in May has the highest ratio (48.5:1), followed August (40.4:1) and October has the lowest (36.4:1). The ratio of all months are higher than 22:1 and the concentration of inorganic phosphorus of all months exceed $0.003 \mathrm{mg} / \mathrm{L}$ indicates that inorganic phosphorus is the limiting factor for the growth of phytoplankton, but has not yet become an absolute 
limiting factor. Phytoplankton absorbs nitrogen and phosphorus nutrients at a ratio of 16:1. The consumption rate of DIN is 16 times higher than phosphorus. From May to August, the nitrogen, phosphorus ratio decreased gradually indicates that the nitrogen, phosphorus ratio in the exogenous supplement is less than 16:1. The ratio of nitrogen and phosphorus in seawater continues to decrease. During phytoplankton blooms in August, the nitrogen and phosphorus is rapidly absorbed into the food chain and fixed. Thus, Nitrogen, phosphorus ratio dropped down to 40.4 in August and further down to 36.4 in October. During October the water and air temperatures are low, which leads to the slowdown of growth of phytoplankton, slowdown of nitrogen, phosphorus consumption, the death of a large amount of phytoplankton, the continued decomposition of biological remains. Part of the Nitrogen and Phosphorus previously entered the food chain returns to the waters. In addition, other exogenous supplement of Nitrogen and Phosphorus such as those released from the seabed sediments will cause nitrogen, phosphorus to slowly accumulate. Since natural Nitrogen is more abundant than natural phosphorus, the supplement of nitrogen is faster than that of phosphorus. Through the accumulation during the low-temperature phase, until the next May when the water temperature starts to raise, the ratio of nitrogen and phosphorus is restored to a higher level, which provides ample nutrients for the spring phytoplankton blooms. In Table 6 , by calculating annual average nitrogen, phosphorus molar ratio at each station, we found that Wuleidao Bay mouth, the inner bay area, Jinghai Bay mouth and an off coast station A07 have higher ratio, which indicate a stronger restrictive effect of the limiting factor phosphorus. Within the studied area, the annual average nitrogen, phosphorus ratio is $41.2: 1$ and the limiting factor is phosphorus nutrient. These observations are consistent with the conclusions of studies on most other rivers and estuaries in the nation.

\section{Conclusion}

(1) DIN meeted the seconed class standard of GB 8978-1996. The distribution characteristics of $\mathrm{NO}_{3}{ }^{-} \mathrm{N}, \mathrm{NH}_{4}{ }^{-} \mathrm{N}, \mathrm{DIN}$ and $\mathrm{TN}$ were similar. All of these nutrients had a higher concentration at the two Bay mouths and the inner bay regions and the concentration decreased seaward. Except for $\mathrm{NO}_{2}{ }^{-} \mathrm{N}$, which had minimal change during the year, the concentration of other various forms of nitrogen nutrients were higher in August than in May and October, mainly due to seasonal river sewage discharge into the sea.

(2) From the estuary seaward, the proportion of DIN in TN increased and the proportion TON in TN decreased due to the assimilation of organic nitrogen, such as urea etc., and DIN to TON by phytoplankton and aquatic plants. Because the relative proportion of the TON in TN increased as the overall level of productivity of the water increases, the Bay and the Bay Estuary area had higher nutrient levels than the open sea. The DIN/TN ratio was close during May and August and was lowest during October because of the introduction of nitrogen from the seasonal river sewage discharge into the sea and the periodic life activities of phytoplankton.

(3) $\mathrm{PO}_{4}^{-3}-\mathrm{P}$ meeted the frist class standard of $\mathrm{GB}$ 8978-1996. The trend of $\mathrm{PO}_{4}^{-3}-\mathrm{P}$ concentration change between each site was not obvious. The sum of DOP and TPP concentration, concentration of TP were higher at the two Bay mouths and the inner bay area 
and decreased seaward. $\mathrm{PO}_{4}{ }^{-3}-\mathrm{P}$ concentrations were high and close in August and October and lowest in May. The TP concentration was higher in August than that of May and October. These observations were because of the introduction of phosphorus from the seasonal river sewage discharged into the sea and the phosphorus fixation followed by the phytoplankton blooms.

(4) $\mathrm{PO}_{4}{ }^{-3}-\mathrm{P}$ was a limiting nutrient for phytoplankton growth in this sea area during the three months, but not an absolute limiting factor. The average monthly nitrogen, phosphorus molar ratio was May> August> October, because of the introduction of phosphorus from the seasonal river sewage discharged into the sea and the periodic life activities of phytoplankton.

(5) Concentration of Chl $a$ was highest at Wuleidao Bay mouth and the inner bay, followed by Jinghai Bay mouth and the inner bay. The lowest concentration appeared off coast. Correlation analysis showed that the correlation of Chl $a$ and $\mathrm{PO}_{4}{ }^{-3}-\mathrm{P}$ was higher than that of Chl $a$ and DIN, which indicated that compared with DIN, the amount of phytoplankton had a closer relationship with inorganic phosphorus concentration.

(6) Without considering COD, August had the highest level of eutrophication, while October was low. When COD was taken into account, both August and October were at a high level, but neither reached the level of eutrophication.

\section{References}

Bricelj, V. M., \& Lonsdale, D. J. (1997). Aureococcus anophagefferens: Causes and ecological consequences of brown tides in U. S. mid-Atlantic coastal waters. Limnol, Oceanogr, 42(5), 1023-1038. http://dx.doi.org/10.4319/lo.1997.42.5_part_2.1023

Brzezinski, M. A. (1985). The Si: C: N ratio of marine diatoms :interspecific variability and the dffect of some environmental variables. Jounal of Phycology, 21, 347-357. http://dx.doi.org/10.1111/j.0022-3646.1985.00347.x

Dortch, Q., \& Whitledge, T. E. (1992). Does nitrogen or silicon limit phytoplankton production in the Mississippi River plume and nearby regions. Continental Shelf Research, 12(11), 1293-1309. http://dx.doi.org/10.1016/0278-4343(92)90065-R

Dubravko, N. R., Justic, R. E., Nancy, T., et al. (1995). Changes in nutrient structure of river-dominated coastal waters: Stoichiometric nurtrient balance and its consequences. Estuarine, Coastal and Shelf Science, 40(3), 339-356. http://dx.doi.org/10.1016/S0272-7714(05)80014-9

Entsch, B., Boto, K. G., Sim, R. G., \& Wellington, J. T. (1983). Phosphorus and nitrogen in coral reef sediments. Limmol. Oceanrgr., 28, 465-476. http://dx.doi.org/10.4319/1o.1983.28.3.0465

Feng, S., Li, F., \& Li, S. (1999). Introduction to Marine Science (p. 503). Beijing: Higher Education Press. 


\section{Macrothink}

Aquatic Science and Technology

ISSN 2168-9148

2015, Vol. 3, No. 1

Froelich, P. N., \& Bender, M. L. (1982). The marine phosphorus cycle. Amer. J. Sci., 82, 474-511. http://dx.doi.org/10.2475/ajs.282.4.474

General Administration of Quality Supervision, Inspection and Quaravtine of the People's Republic of China, Standardization Administration of the People's Republic of China. (2007). GB 17378.4-2007 The specification for marine monitoring-Part 4: Seawater analysis. Beijing: China Standard Press.

General Administration of Quality Supervision, Inspection and Quaravtine of the People's Republic of China, Standardization Administration of the People's Republic of China. (2007). GBT 12763.4-2007 Specifications for oceanographic survey-Part 4: Survey of chemical parameters in sea water. Beijing: China Standard Press.

George, A. J., \& Willianms, P. M. (1985). Importance of DON and DOP to biological nutrient cycling. Deep-Sea Res., 32, 223-235. http://dx.doi.org/10.1016/0198-0149(85)90030-5

He, T., Xie, J., Fang, H., et al. (2008). Status and evaluation on nutrients in Daya Bay in spring. Marine Environmental Science, 27(3), 220-223.

Justic, D., Rabalais, N. N., \& Turner, R. E. (1995). Stoichiomertic nutrient balance and origin of coastal eutrophication. Marine Pollution Bulletin, 30, 41-46. http://dx.doi.org/10.1016/0025-326X(94)00105-I

Li, G., Cui, Y., Chen, B., et al. (2007). Status and evaluation on nutrients in Laizhou Bay in Autumn. Marine Environmental Science, 26(1), 45-57.

Ministry of Environmental Protection of the People's Republic of China. (1997). GB3097-1997 the People's Republic of China Sea water quality standard.

Odun, E. P., (1981). The ecological basis (Sun, R., Qian, G., et al. Trans, pp. 83-100). Beijing: People's Education Press.

Pomeroy, L., \& Simith, E. E. (1965). The Exchange of phosphate between estuaries water and sediments. Liminol. Oceanogr, 10, 167-172. http://dx.doi.org/10.4319/1o.1965.10.2.0167

Quriós, R. (2003). The relationship between nitrate and ammonia concentrations in the pelagic zone of lake. Limnetica, 22(1-2), 37-50.

Stumm, W., \& Morgan, J. (1996). Aquatic chemistry: Chemical equlibria and rates in nature waters (3rd ed. pp.927-932). NY: John Wiley \& Sons.

Sun, P., Wang, B., Zhang, Z., et al. (2006). The relationship between nutrient distributions and eutrophication of Laizhou bay seawater. Advances in Marine Science, 24(3), 229-335.

Wetzel, R. G. (2001). Limnology: Lakes and river ecosystems (pp. 204-238). CA: Academic Press.

Yang, D., Zhang, J., Dong, Y., et al. (2001). The uniqueness of nutrient limitation, 25(12), 49-51.

Zhang, J., \& Shen, Z. (1997). Study on the changes in nutrient structure of Jiaozhou Bay. 


\section{Macrothink}

Oceanologia Et Limnologia Sinica, 28(5), 529-534.

Zhang, Z. (2004). Marine Chemistry (pp. 118-138). Qingdao: Ocean University of China press.

\section{Copyright Disclaimer}

Copyright for this article is retained by the author(s), with first publication rights granted to the journal.

This is an open-access article distributed under the terms and conditions of the Creative Commons Attribution license (http://creativecommons.org/licenses/by/3.0/). 